\title{
ACCOUNTING EDUCATION: A THEORETICAL OVERVIEW
}

Khadidja REDDA $^{\text {a }}$, Zakarya KHALFALLAH ${ }^{\mathrm{b}}$,

a. k.redda@univ-dbkm.dz, Khemis Miliana’s University,Algeria. b. zakarya.khalfallah@univ-dbkm.dz, Khemis Miliana’s University,Algeria.

Received date: 20/ 05/2021, Accepted date: 15/ 06/2021, online publication date: 30/ 06/2021

\begin{abstract}
The main purpose of this paper is to highlight the Accounting Education as a real asset that must continually evolve in order to best prepare future professionals on accounting for the new requirements imposed by technology and globalization. To do this, a descriptive methodological approach has been deployed to present Accounting Education Standards (IESs), which are developed by the International Accounting Education Standards Board (IAESB). These standards are influencing Accounting Education and training worldwide. The goal of the IESs is to ensure that economic decision makers can rely on the competence of professional accountants regardless of the country where the accountants received their education and training.

Two major lessons emerge from this study. On the one hand, that the organizational structure, globalization and technology impact the skills needs of the accountancy profession and, on the other hand, there is a gap between the training provided and the needs of the profession.
\end{abstract}

Keyword: Accounting Education; Accountancy profession; IESs; IAESB.

JEL Code: M41; A29.

One of the central issues in the functioning and maintenance of a profession is the way in which individuals are prepared to become professionals, and so it is for the accountancy profession.

In the past, the accounting faced so many problems, it didn't attract enough of the right students, and most of the graduates lack the capabilities demanded by employers. The accounting programs were held in low esteem among many university administrators, that some think Accounting Education and research are not central to the university's mission, and that others view it as a fringe discipline that should be reserved only as a professional one.

In other words, the gap between researchers and practitioners is caused by practitioners who deal with research too technical, and researchers who are accused of

\footnotetext{
^ Corresponding Author
} 
taking on narrow problems rather than dealing with fundamentals. And the consequence is that academic research in accounting has little effect on professional policy.

In the 19th century, with the appearance of the industrial revolution, the accounting profession has reached a crossroad. Will it take the road labeled "more debits and credits for the bygone industrial age' or will it take the road labeled "decision support for the information age?"

Now, our economy has changed and continues to change rapidly by revealing new information technologies systems. These later, beside certain factors such as technology and globalization (which have an important impact on Accounting Education and accounting educators: not only does it impact the curriculum, it also places demands on both instructors and students. That's why, globalization has affected many aspects of life, including the accounting profession) have brought about fundamental changes in the way of doing business and brought to light new needs that the accountancy profession must meet.

If the accounting profession can identify properly those measurements and devise ways to make and report them reliably, the need for Accounting Education will be unquestioned and the researchers who bring that about will be widely read and appreciated.

Accounting Education must therefore continually evolve in order to best prepare future professionals for these new requirements and it's up to Accounting Education institutions who must respond to the changes by providing education systems that comply with market expectations.

Many of the discussions surrounding this issue revolve around harmonization of international accounting standards and the adoption of IFRS (International Financial Reporting Standards) in various jurisdictions around the world. Naturally, the adoption of International Financial Reporting Standards (IFRS) in most countries of the world has a great impact, but it is only part of a wider movement that includes the globalization of business. (Belverd $\mathrm{Jr}, 2010$ ), this is why there are more discussions that revolve around Accounting Education internationalization while highlighting International Education Standards (IESs), these later are set by the Accounting Education Standards Board (IAESB).

And, it is in this context that our research problem is set up:

Which place does Accounting Education should take on to face new requirements of accounting profession?

In order to answer the above problem, we will subdivide it into sub-questions as follows:

* Why internationalization of Accounting Education is so important for the accountancy as a profession?

* How would this internationalization be insured?

As hypothesis for those above questions, we can say:

* The internationalization of Accounting Education derives its importance from the importance of the gap between academic research and practice in the field of accounting. 
The internationalization would be insured by setting an international standards that should be accepted and applied across the world.

In order to provide some answers to our research problem, we will adopt a descriptive methodology, while subdividing our study to two parts, the first will be presenting the IAESB in general: its mission, its objectives ... in the second one, we will give a brief idea of the IES.

\subsection{Research objectives}

We summarize the objectives of our article in the following points:

* bring more light on the gap between academic research and practice in the field of accounting;

* presenting the IESs and its importance for the accountancy' enhancing;

* presenting the IEASB as an international setter of the IESs.

\subsection{Literature review}

\section{The study of (Helena COSTA OLIVEIRA):}

According to the authors, Accounting Education had to evolve in order to acknowledge and take advantage of information technologies. These technologies are important in creating a credible simulation and better support to both students and teachers. We present a qualitative case study of a course of business simulation based on the use of information technologies. Developed by a Portuguese accountancy college, this employment-driven subject relies on two kinds of technologies: educational and entrepreneurial. This learning process improves students' confidence on addressing the challenging professional world. In order to achieve this goal, the college had to deal with significant financial and human resources.

* The report of (Belverd E \& Needles Jr, 2009)

Its report investigates the impact of globalization on Accounting Education as set forth by members of a panel at the annual meeting of the American Accounting Association held in New York in August 2009. It addresses the work of the International Federation of

Accountants (IFAC) and the International Accounting Education Standards Board (IAESB) in coordinating Accounting Education globally, research by the International Association for Accounting Education and Research (IAAER) in support of the IAESB, the work of the International Accounting Standards Committee Foundation (IASC Foundation) and its impact on Accounting Education, and the impact of globalization on Accounting Education in Japan.

* The paper of (Bui \& Hoang \& Phan and Yapa, 2017):

In their turn, the researchers investigated the influence that stakeholders for one state-owned university in Vietnam had on developing and delivering an accounting curriculum.

The authors interviewed accounting program stakeholders $(n=17)$, including academic administrators, accounting faculty (referenced as lecturers), students, employers, a professional body, and a government official. Interviews revealed that 
the Vietnamese government exercised limited control over Accounting Education, while employers and a professional accounting body had the most influence on the curriculum development and approval process. Accounting faculty did not participate in curriculum decision-making, although they decided on course delivery methods, teaching materials, and assessment. Accounting educators will find this article useful for understanding the Vietnamese higher education system.

\section{The dissertation of (H van Romburgh, may 2014):}

This study aimed to determine the skills shortages in first-year trainee accountants entering practice in South Africa and to recommend ways to improve such shortages. Questionnaires were administered to registered audit firms in the Gauteng Province, South Africa in which the perceptions of trainees, managers and partners on the skills shortages in first-year trainee accountants were gathered. The overall feeling of respondents seemed to be that universities do not sufficiently equip first-year trainees with the skills to be successful in practice, especially professional communication and a lack of exposure regarding computer accounting software packages. Professional bodies and universities should work together to overcome skills shortages.

The studies above treats professional accountancy programs as useful as it provides and ensures the development of Accounting Education, if weaknesses are identified and acted upon, it may result in a strengthening of the professional Accounting Education system which could result in a better informed market. It may also help with ensuring that skills become more transportable across all over the world.

\section{Why is Accountancy Education Relevant?}

Enhancing education through developing and implementing IESs should increase the competence of the global accountancy profession and contribute to strengthened public trust. To meet the continual challenges facing the global economy, the accountancy profession needs to ensure that individuals who become professional accountants achieve an agreed level of competence, which is then maintained.

Competence is developed and sustained through initial education and practical experience, followed by continuing professional development. The profession, therefore, needs to set and meet high educational standards in these three areas. Enhancing education serves the public interest by contributing to the ability of the accountancy profession to meet the needs of decision makers (International Federation of Accountants, 2011).

\section{What is the IAESB?}

The International Accounting Education Standards Board is an international non-state, private standard setter; that serves the public interest by strengthening the worldwide accountancy profession through the development and enhancement of education. Through its activities, the IAESB enhances education by developing and 
implementing International Education Standards, which increases the competence of the global accountancy profession-contributing to strengthened public trust (International Federation of Accountants, 2011).

The standards it pronounces are not based on, or mandated by, national or international law. Indeed, the IAESB needs to influence professional Accounting Education in jurisdictions where the states regulate and enforce practice and may not recognize the IAESB as a legitimate organization within the national regulatory regime.

The structures and processes that support the operations of the IAESB are facilitated by the International Federation of Accountants (IFAC), a global organization for the accountancy profession. IFAC is comprised of 164 members and associates in over 125 countries and jurisdictions, representing approximately 2.5 million accountants in public practice, education, government service, industry, and commerce.

NB: Both IFAC and IAESB play prominent roles in the globalization of accounting standards.

The stated mission of IFAC is as follows (Belverd E. Needles Jr, 2010):

* To serve the public interest, strengthen the worldwide accountancy profession and contribute to the development of strong international economies.

* Establish and promote adherence to high quality professional standards.

* Further the international convergence of such standards.

* Speak out on public interest issues where the profession's voice is most relevant.

\subsection{IAESB Objectives}

In addition to IFAC, the IAESB also plays a significant role in the globalization of accounting standards. The IAESB has set objectives of (Belverd E \& Needles Jr, 2010):

* Establishing a series of internationally-relevant standards and other pronouncements reflecting good practice in the learning, development and assessment of professional accountants.

* Developing education benchmarks for measuring the implementation of International Education Standards.

* Advancing international debate on emerging issues relating to the learning, development and assessment of professional accountants.

\subsection{IAESB Structure and Governance}

Here below we set a brief presentation of the IAESB Structure and Governance

Figure 1: IAESB Structure and Governance: 


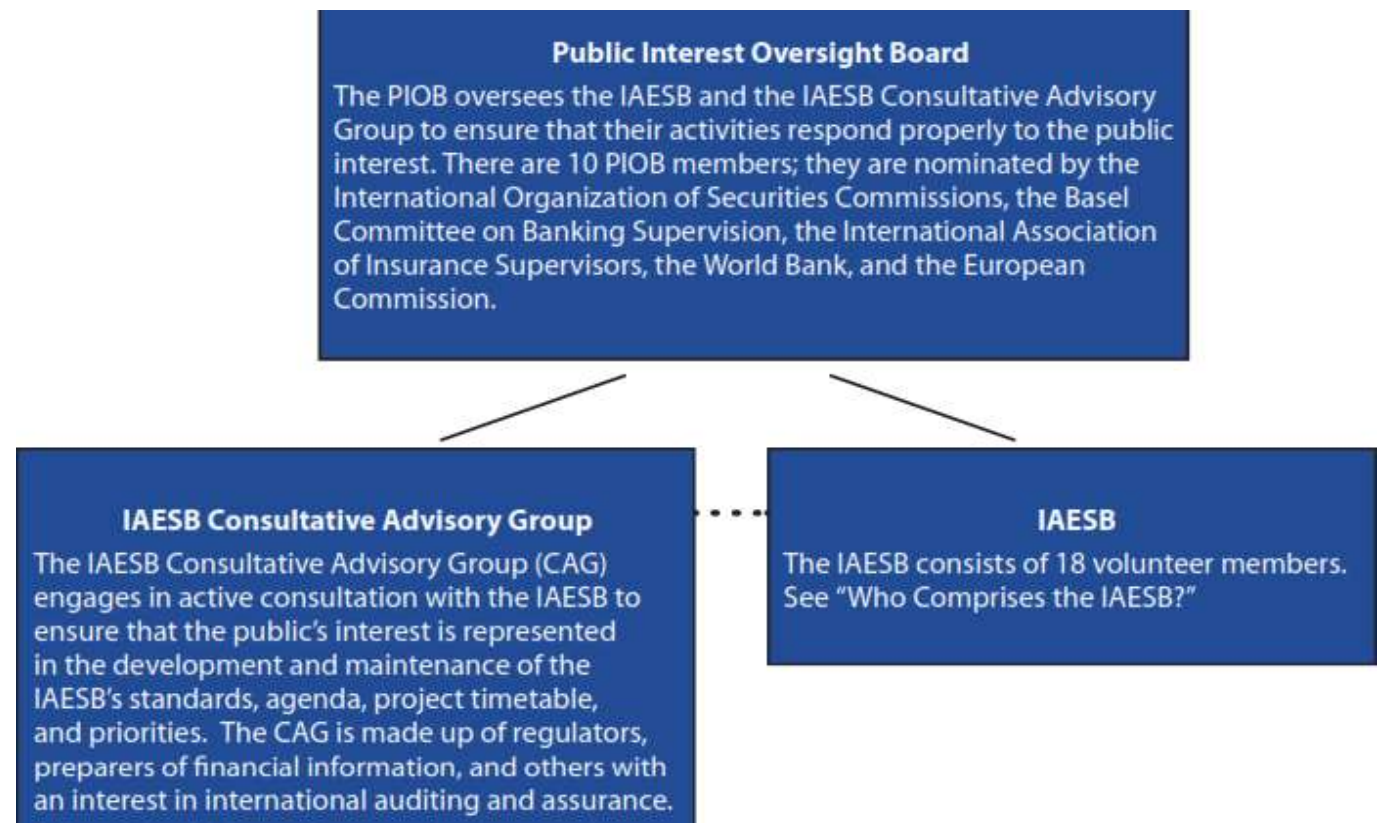

Source : www.ifac.org, june 2011.

\section{Why International Education Standards?}

The IESs assist professional accountancy organizations, regulators, employers, academics, and students by prescribing principles for the learning and development of professional accountants. These standards are being set up to fill the gap between university and practice.

The gap in Accounting Education standards discussed in the introduction seems to extend to accounting practice. Even as far back as 1990, Patton and Williams suggested that the fundamental flaw in Accounting Education is that it has remained stagnant while the profession has changed (Ainsworth P, 2001)- and at that stage, the profession was not changing nearly as fast as it is today.

There is a growing agreement among accounting professionals that recent accounting graduates do not adequately meet the high standards set by potential employers (Clovey R. \& Oladipo, 2008)Teaching methods at universities often lack creativity, involve too much lecturing and dependence on textbooks, and do not develop the students' capability to learn skills. Educators are too bound by their class time and do not require enough student contact with business. Furthermore, the curricula are too restricted, often outdated or irrelevant, and often shaped by the interests of the faculty instead of the demands of the market (Albrecht W.S. \& Sack, 2000).

Therefore, globally accepted standards should minimize differences among countries and jurisdictions, thus reducing international differences in the requirements to qualify and work as a professional accountant. In addition, they should increase the opportunity for mobility of labor, and in doing so, contribute to the global economy (International Federation of Accountants, 2011).

This is why, The IAESB issues International Education Standards, which contain guidelines for teaching accounting globally. These standards can assist global Accounting Education by providing a global framework for education, prescribing the 
range of professional knowledge, professional skills, professional values, ethics and attitudes required, instilling an attitude of lifelong learning, and providing a foundation for the application of professional and technical standards.

To date, the IAESB has formulated eight (08) International Education Standards and three International Education Practice Statements. Other IAESB pronouncements include Information Papers, International Education Papers, and Tool Kits. The IAESB will engage the academic community by encouraging it to assist in developing and reviewing IAESB pronouncements, commenting on Strategic Plan development, providing academic research and assisting in training the professionals of the future (Belverd Jr, 2010).

The IFAC Statements of Membership Obligations (SMOs) summarize the requirements for IFAC member bodies. SMO 2 requires compliance with IAESB International Education Standards (IES) but this is only mandatory if the IFAC member body is directly responsible. According to IFAC "globally accepted standards should minimize differences between countries and jurisdictions, thus reducing international differences in the requirements to qualify and work as a professional accountant". IFAC does not address responsibility for qualifications and accepts differences between countries. The IES are promoted as benchmarks; recognition of qualifications between countries is not considered as a specific subject (Brisejda RAMAJ ZENUNI Mire \& la UJKANI MITI, 2017).

And here below the list of the standards issued by the IAESB:

Figure 2: International Education Standards

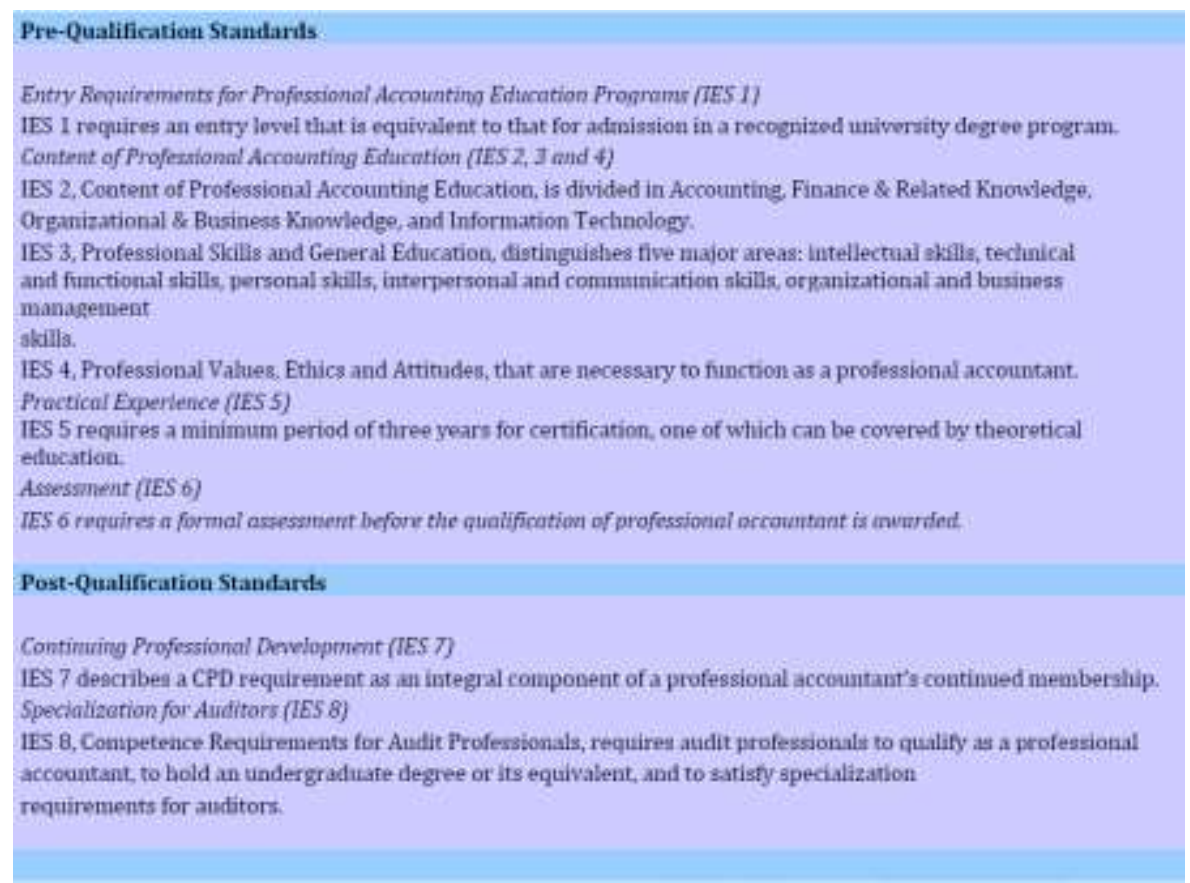

Source: Global Accountancy Education Recognition Study 2012 (NASBA, 2012) (NASBA 2013)

The most recent IES revision is the newly revised IES 7 Continuing Professional Development, which was published on 28 January 2019 and to be effective from 1 
January 2020. Besides this, the IAESB, is also in the process of revising IES 2, 3, 4 and 8 with emphasis on information and communication technologies (ICT) and professional skepticism, two traits deemed essential to be possessed by professional accountants in this technology era. These revisions arise because the IAESB concluded that current versions of IES did not adequately address the accounting profession's current and future needs in ICT and professional skepticism areas. This conclusion was based on several information gathering activities organized by the IAESB (TakeAmelia Limijaya, 2020).

On December 2018, after taking into account consultations with stakeholders and insight from various sources, an exposure draft was released and comments/ feedbacks from stakeholders were expected. This article discusses the responses received from stakeholders and highlights several lessons that can be learned from this process, to give recommendations to the IAESB as well as stakeholders of Accounting Education, with the purpose of advancing the accounting profession through Accounting Education global standards, to better serve the public interest.

The Exposure Draft (IAESB 2018) details the proposed changes for each IESs along with the rationale for such changes. For IES 2, the author identified 9 new learning outcomes (LO): one for the audit and assurance technical competence; two for governance, risk management and internal control; one for business laws and regulations; four for the information and communication technologies; one for business and organizational environment. Meanwhile, there are 4 new LO identified for IES 3: two for intellectual skill, one for interpersonal and communication skill, and one for personal skill. In IES 4, two LO are added to professional skepticism and professional judgment, whereas one is added to ethical principles. Lastly, there are 9 new LO added to IES 8: two for audit competence area, one for interpersonal and communication, one for personal, four for professional skepticism and professional judgment, and one for ethical principles. In addition to new LO, for each respective IES there are also some modifications, which consist of wording changes, revisions, repositions, as well as removal of existing LO due to reasons such as content overlapping and replacement by other LO. Some IES have LO that act as indicators of the required knowledge, understanding and application in each of the competence area.

Besides the above-mentioned proposed changes, the Exposure Draft also define three terms: information and communication technology, intellectual agility, and professional judgment, of which response or comments are expected (TakeAmelia Limijaya, 2020). 
Figure 3: Competency sub-pillars of accountancy education

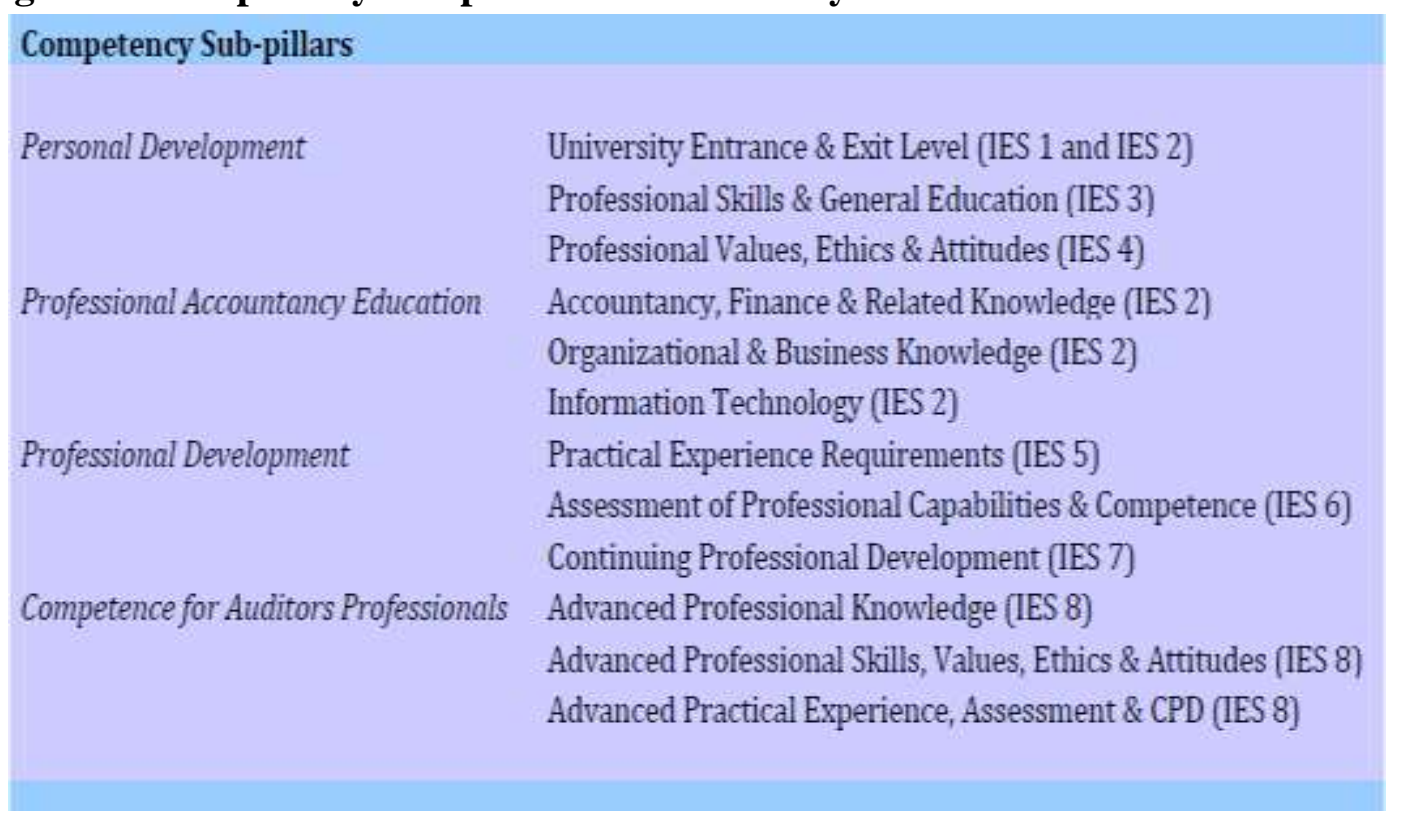

Source: (GAE, 2012), Dynamics of Global Accountancy Education

According to the figure above (Brisejda RAMAJ ZENUNI \& Mirela UJKANI MITI, 2017), Sub-pillar 1, personal development, combines elements that in many countries are achieved through university education.

Sub-pillar 2, professional accountancy education, emphasizes competences in accounting, finance \& related knowledge; in organizational \& business knowledge; and in information technology. Normally courses are provided by universities and/or professional accountancy organizations.

Sub-pillar 3, professional development, combines practical experience, assessment of professional competence, and CPD.

Normally the accountancy profession is leading in these areas.

Sub-pillar 4, competency for audit professionals, includes higher level requirements for licensed accountants and auditors.

\section{CONCLUSION}

The main purpose of this paper was trying to provide some answers to the problem:

Which place does Accounting Education should take on to face new requirements of accounting profession?

At this point we can conclude that According to (Lehman, 2005), the term 'globalization' refers to the economic consequences of internationalization which Enable expansion of trade and commerce between countries. Advocates of globalization promote the ideology of capital market liberalization and believe this will be enabled by international harmonization of accounting and audit practice (Lehman G. , 2009) The quality of Accounting Education underpins the effective implementation of accounting and auditing standards by professional accountants.

However, the quality and content of professional accounting training programs has been criticized over the years, particularly as professional training stresses the 
technical aspects and fails to deliver on skills, ethics, accountability, transparency and good corporate governance. The pronouncements of the IAESB aim to mitigate these concerns by attempting to standardize and mandate rigorous programs for trainee accountants prior to admittance to membership of an IFAC member body. For the IAESB to be successful, it is not unreasonable to argue that, its IESs have to be accepted and implemented consistently by education practitioners operating in diverse jurisdictions across the globe (Louise Crawford \& Christine Helliar \& Elizabeth Monk and Monica Veneziani, 2014).

In addition of that, and according to what have been treated in this study, we can now discuss the hypothesis listed in the introduction:

- It's totally true that the internationalization of Accounting Education derives its importance from the importance of the gap between academic research and practice in the field of accounting, however, this gap should be eliminated to ensure a high quality of Accounting Education. In other words, there is an inverse relationship between them.

- The internationalization would be insured by setting an international standards that should be accepted and applied across the world, this hypothesis is also true and this is what the IAESB have done by creating the IESs

\section{SOME RECOMMENDATIONS}

By way of recommendations, we say:

- Research should focus on the creation of knowledge of potential use to students in developing their capabilities for practice.

- Accountabilities should be rethought, accounting information should help entities attain goals. Therefore, an accounting system should have methods of relating past - or cause - to future - or effect.

- Accounting Education, has to respond to the present information technology requirements by adjusting the education system. In other words, technology advanced must be incorporated with the education process to get the benefits of sophisticated technology in terms of teaching method and media, especially and above all when the traditional learning process is considered no longer attractive among the millennial generation.

- Furthermore, Accounting Education should also take care curriculum to be adjusted with the need of the industry and current business practice.

\section{REFERENCES}

Ainsworth P. (2001). Changes in accounting curricula: discussion and design. Accounting Education, pp. 279-297.

Albrecht W.S. \& Sack, R. (2000). Accounting education: charting the course through a perilous. Sarasota, FL: American Accounting Association. 
Belverd E \& Needles Jr. (2010). Accounting Education: The Impact of Globalization. Accounting Education, pp. 601-605.

Belverd E \& Needles Jr, B. (2009). Accounting Education: The Impact of Globalization. New Yourk.

Brisejda RAMAJ ZENUNI \& Mirela UJKANI MITI. (2017, Sep. Dec.). Compliance with International Education Standards of Accounting in European Union Countries, the Case of Albania as An Official Candidate for Accession to The EU. European Journal of Social Sciences Education and Research.

Bui \& Hoang \& Phan and Yapa. (2017). Governance and compliance in accounting education in Vietnam - case of a public university. journal of Accounting Education .

Clovey R. \& Oladipo, O. (2008). The VITA program: a catalyst for improving accounting education. CPA Journal, 78(12), pp. 60-65.

GAE. (2012). Dynamics of Global Accountancy Education.

H van Romburgh. (may 2014). Accounting education: Investigating the gap between school, university and practice. Dissertation submitted in fulfillment of the requirements for the degree Magister Commercii in Accounting at the Potchefstroom.

Helena COSTA OLIVEIRA, H. (s.d.). TECHNOLOGY IN ACCOUNTING EDUCATION: A BUSINESS SIMULATION CASE STUDY. Porto: CECEJ / ISCAP Polytechnic Institute .

International Federation of Accountants. (2011, june). retrieved from www.ifac.org

Lehman, G. (2005). critical perspective on the harmonisation of accounting in a globalised world. Critical Perspectives on Accounting, pp. 975-992.

Lehman, G. (2009). Globalization and the internationalization of accounting: New technologies, instrumentalism and harmonization . Critical Perspectives on Accounting, pp. 445-447.

Louise Crawford \& Christine Helliar \& Elizabeth Monk and Monica Veneziani. (2014). International Accounting Education Standards Board: Organisational legitimacy within the field of professional accountancy education . Accounting Forum 38 , pp. 67-89.

NASBA. (2012). Global Accountancy Education Recognition Study.

TakeAmelia Limijaya. (2020, July-December). IES Proposed Revisions: Takeaway Lessons to Enhance International Accounting Education Standards Convergence. JURNAL PENDIDIKAN AKUNTANSI DAN KEUANGAN, pp. $123-140$. 